\title{
Idiopathic Gingival Enlargement with Aggressive Periodontitis Treated with Surgical Gingivectomy and $0.2 \%$ Hyaluronic Acid Gel (Gengigel $^{\circledR}$ )
}

\author{
${ }^{1}$ Kharidhi L Vandana, ${ }^{2}$ Priyanka Dalvi, ${ }^{3}$ Neha Mahajan
}

\begin{abstract}
Background: Idiopathic gingival fibromatosis is known to be a benign slow growing proliferation of the gingival tissue. It is genetically heterogeneous, associated with syndromes and rarely presents as an isolated disorder. Aggressive periodontitis $(A P)$ is a disorder that results in severe rapid destruction of the tooth-supporting apparatus and is also a genetically transmitted disorder of the periodontium. In the case of gingival enlargement there will be an excessive display of gingiva affecting the esthetic and functional problems. Gingival enlargement in association with generalized AP is very rare.
\end{abstract}

Case description: A 23-year-old female was reported with a recurrence of gingival enlargement along with generalized tooth mobility. On detailed history, clinical and laboratory findings, it was diagnosed as recurrent idiopathic gingival enlargement with generalized aggressive periodontitis. This patient has been followed up for nearly 9 years ever since she first reported to us in the year 2004 with a similar finding. Treatment included extraction of teeth with a hopeless prognosis, through phase I therapy, local drug delivery of gengigel ${ }^{\circledR} 0.2 \%$ hyaluronic acid, gingivectomy using electrocautery, follow up visits and prosthetic rehabilitation using a treatment partial denture.

Conclusion: In generalized AP, rapid destruction of periodontal tissues can be prevented by early diagnosis. Also, diagnosis of GAP can be complicated by associated conditions like gingival enlargement. Therefore the diagnosis should be based on complete history radiographical microbiological and clinical findings. The use of local application of agents such as Gengigel ${ }^{\circledR}$ is recommended to improve the periodontal condition.

Keywords: Aggressive periodontitis, Gingival enlargement, Gingivectomy, Gengigel ${ }^{\circledR}$, Local drug delivery.

How to cite this article: Vandana KL, Dalvi P, Mahajan N. Idiopathic Gingival Enlargement with Aggressive Periodontitis Treated with Surgical Gingivectomy and 0.2\% Hyaluronic Acid Gel (Gengigel $\left.{ }^{\circledR}\right)$. CODS J Dent 2017;9(1):36-40.

Source of support: Nil

Conflict of interest: None

\footnotetext{
${ }^{1}$ Senior Professor, Former Associate Dean, ${ }^{2}$ Postgraduate Student, ${ }^{3}$ Senior Lecturer

1,2Department of Periodontics, College of Dental Sciences, Davangere, Karnataka, India
}

${ }^{3}$ Department of Periodontics, Himachal Dental College, Himalchal Pradesh, India

Corresponding Author: Kharidhi L Vandana, Senior Professor, Former Associate Dean, Department of Periodontics, College of Dental Sciences, Davangere, Karnataka, India e-mail: vanrajs@gmail.com

\section{INTRODUCTION}

In inflammatory periodontal diseases, gingival enlargement will be a common finding. Based on the etiologic factors and histopathologic findings, there are several kinds of gingival enlargement. Gingival enlargement induced by drugs such as phenytoin, cyclosporine, and calcium channel blockers associated with systemic disorders produced by hormonal factors, leukemia, vitamin $\mathrm{C}$ deficiency, and idiopathic gingival fibromatosis have been reported. ${ }^{1}$

Aggressive periodontitis (AP) is a rare condition of periodontitis which can be localized (LAP) or generalized (GAP) based on the clinical and laboratory findings. A case may be diagnosed as AP if it presents with the major common features ${ }^{2}$ like non-contributory medical history, rapid attachment loss, bone destruction, and familial aggregation, according to the 1999 International classification workshop. Secondary features that are generally present but may not be seen with AP include; the amount of microbial deposits inconsistent with the severity of periodontal destruction; the elevated proportion of Aggregatibacteractinomycetemcomitans (Aa); phagocyte abnormalities, hyper-responsive macrophages, producing increased $\mathrm{PGE}^{2}$ and IL and in some cases, self-arresting disease progression.

The GAP represents the most heterogeneous group and includes the most severe forms of periodontitis previously diagnosed as generalized juvenile periodontitis, GAP may be diagnosed based on findings: ${ }^{3}$ persons under 30 years (however maybe older), generalized interproximal loss of attachment affecting at least three permanent teeth other than first molars and incisors, pronounced episodic nature of periodontal destruction and poor serum antibody response to infecting agents. Some patients of GAP may present with systemic manifestations such as weight loss, depression and general malaise. $^{2}$

The GAP usually presents as severe acute gingival inflammation associated with bleeding on probing; pink gingival tissues, free of inflammation and occasionally with some degree of stippling seen. ${ }^{4}$ Gingival enlargement is an infrequent finding in a case of GAP. 
It is not always possible to identify the precise cause of gingival enlargement. The following report will present a case of GAP with gingival enlargement and discuss its periodontal management by surgical and local delivery of $0.2 \%$ hyaluronic acid gel $\left(\right.$ Gengige $\left.{ }^{\circledR}\right)$.

\section{CASE REPORT}

The patient was an Indian girl, 23 years of age, who consulted for the treatment of recurrent gingival enlargement, increased spacing and mobility in her teeth. She was systematically healthy, and there was no history of any drug intake. She had no habit of drinking or smoking, and her family history did not reveal any significant information related to her present condition. Episode of gingival enlargement had occurred in the year 2004, when she was 14 years old she reported with swollen gums of the left side of both upper and lower jaws since three years which was gradual on onset, inability to chew food from that side, bleeding gums while brushing teeth and bad breath since 2 to 3 months. Inspectory findings were confirmed on palpation. The details of findings are listed in Table 1.

She underwent thorough phase I therapy, extraction of hopeless teeth, internal bevel gingivectomy, and use of electrocautery permitted adequate contouring of the tissues with periodic revaluation, and the case was followed up for 2 years with regular supportive periodontal therapy and instructions to report if any recurrence of any gum enlargement.

The condition resolved after professional care and maintenance by the patient. The gingival enlargement reappeared after the treatment for which the patient tried to avail treatment from non-institutional doctors but in vain. The patient failed to report for regular follow-ups later until she reported again in the year 2013 with a similar chief complaint of swollen gums and inability to chew food.

The details of the clinical findings and the treatment at different periods are listed out in the Table 1.

\section{Treatment Planning (Table 1)}

Periodontal treatment planning included internal bevel gingivectomy for the gingival enlargement and was explained to the patient. The patient was given proper oral hygiene instructions. Phase I therapy was initiated with thorough scaling and root planning. Followed by extraction of hopeless teeth. Excision of gingival enlargement was performed under local anesthesia, the patient was followed for two weeks, and gengigel application as local drug delivery agent was applied on surface and intrasul- cularly in molars and incisors for three weeks. Gengige ${ }^{\circledR}$, i.e. $0.2 \%$ hyaluron gel has an anti-inflammatory and antioedematous effect and promotes wound healing Studies have asserted that application of gengige ${ }^{\circledR}$ or hyaluron gel $(0.2 \%)$ in adjunct to scaling root planning may have beneficial effect on periodontal health in patients with chronic periodontitis. The anti-inflammatory effect of HA occurs by its action of de-activating bacterial hyaluronidases, normalizing the macro-aggregation of connective tissue proteoglycans, and bonding with free water, thus causing an anti-edema effect. Also HA is a natural and essential extracellular matrix substance that promotes healing by stimulating angiogenesis, has bacteriostatic and antiseptic properties, maintains the structural integrity of the tissues, regulates hydration of tissues and cell physiology, protects the tissues by formation of a barrier, stimulates pro-inflammatory cytokines production, regulates the phagocytic migration, prevents colonization of bacteria, stimulates granulation tissue formation and healing, interacts with growth factors for the development of mineralized and non-mineralized tissues, and is locally absorbed when applied to tissues. ${ }^{5}$ The gingival condition of the patient improved following professional care and maintenance therapy. The patient was referred to Department of Prosthodontics for occlusal rehabilitation. A treatment partial denture replaced the extracted teeth.

\section{DISCUSSION}

This paper reports superimposition of recurrent idiopathic gingival enlargement in a patient with generalized AP. The patient reported with swollen and bleeding gums 9 years ago. In the present case, the patient was systematically healthy and under no medication which could contribute to gingival overgrowth. She also did not give a history of pregnancy. General physical examination of the patient revealed no syndromic association which could contribute to gingival overgrowth. The clinical, histopathological features and systemic examination exclude the diagnosis of an enlargement of neoplastic origin. Gingival enlargement is also associated with scurvy; ${ }^{1}$ however, our patient did not present with other signs of scurvy such as petechiae, ecchymosis or spontaneous bruising of the extremities. All the hematological investigations were within normal limits. Histopathological examination revealed hyperplastic epithelium with elongated rete ridges and densely arranged collagen bundles. These histological findings of our patient were consistent with those for fibrous gingival hyperplasia. The diagnosis of generalized idiopathic gingival enlargement was made based on previous history, clinical, histopathological and radiographic finding. 
Table 1: Clinical, radiographic findings and treatment at different time period

\begin{tabular}{|c|c|c|c|}
\hline Findings & 2004 & 2006 (follow-up) & 2012 \\
\hline Clinical findings & $\begin{array}{l}\text { Bilaterally palpable submandibu- } \\
\text { lar lymph nodes }\end{array}$ & Not significant & - Non-significant \\
\hline Gingival status & $\begin{array}{l}\text { Generalized diffuse gingival } \\
\text { enlargement grade III (Boken- } \\
\text { kam et al. 1994) smooth and } \\
\text { edematous seen in the buccal } \\
\text { palatal and lingual aspect in all } \\
\text { quadrants } \\
\text { except in lower right quadrant } \\
\text { - Generalized bleeding on probing } \\
\text { (Fig. 1) }\end{array}$ & $\begin{array}{l}\text { - There was no recurrence of gingival } \\
\text { enlargement. } \\
\text { Bleeding on probing in relation to } \\
12,14,16,22,2324,34 \text { and } 35\end{array}$ & $\begin{array}{l}\text { - Recurrence seen after } 6 \text { years } \\
\text { Presented as gingival enlargement } \\
\text { with bright red seen in maxillary } \\
\text { right and left quadrant involving } \\
\text { buccal gingiva and palatal gingiva } \\
\text { and in mandibular left quadrant } \\
\text { involving buccal gingiva. The man- } \\
\text { dibular right quadrant being rela- } \\
\text { tively less affected } \\
\text { - (Grade III Bokenkamp et al. 1994) } \\
\text { - Bleeding on probing seen (Fig. 4) }\end{array}$ \\
\hline Periodontal status & 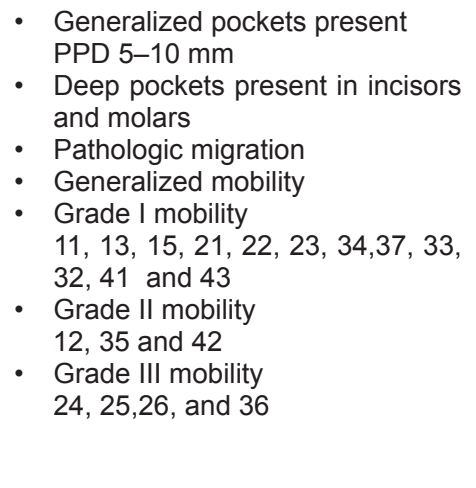 & $\begin{array}{l}\text { - PPD improved } \\
\text { - Mobility of the teeth improved } \\
\text { Grade II mobile teeth in the first visit } \\
\text { turned into grade I mobile teeth } \\
\text { Grade I mobility : } \\
\begin{array}{l}11,13,15,21,22,23,34,37,33 \text {, } \\
32,41,43,12,35 \text {, and } 42\end{array}\end{array}$ & $\begin{array}{l}\text { - Generalized pockets } \\
\text { - Deep Pockets : } \\
\text { 12, } 13,14,15,16,24,27,46 \text { and } \\
47 \\
\text { - } \text { Probing pocket depth } 5 \mathrm{~mm}-8 \mathrm{~mm} \\
\text { - } \text { Deep pockets were present in inci- } \\
\text { sors and molars areas } \\
\text { - } \text { Pathologic migration } \\
\text { - Grade I mobility: } \\
\quad 11,13,15,17,18,28,37,34, \\
\quad 47,33,43,44,45 \text { and } 48 \\
\text { - } \text { Grade II mobility: } \\
\text { - } 32,31,41 \text { and } 42 \\
\text { Grade III mobility: } \\
12,14,16,22,23,24,27,35 \text { and } 46\end{array}$ \\
\hline $\begin{array}{l}\text { Radiographic findings } \\
\text { (OPG) }\end{array}$ & $\begin{array}{l}\text { - Generalized bone loss } \\
\text { - Severe bone loss seen around } \\
46 \text { reaching the apical third of the } \\
\text { root }\end{array}$ & $\begin{array}{l}\text { Remarkable finding in relation to } \\
\text { 46.The radio density seen around } \\
46 \text { suggestive of bone fill (Fig. } 3 \text { ) }\end{array}$ & $\begin{array}{l}\text { OPG revealed progressive bone } \\
\text { loss throughout the dentition }\end{array}$ \\
\hline Dental status & $\begin{array}{l}\text { - } 46-\text { EPT test positive } \\
\text { Endodontically tooth } 46 \text { was } \\
\text { healthy } \\
\text { - Erupting } 18,28 \text { and } 38 \\
\text { - } 38 \text { Open bite present }\end{array}$ & $\begin{array}{l}\text { Missing: } \\
24,25,26 \text { and } 36 \\
\text { (extracted owing to poor periodontal } \\
\text { prognosis) }\end{array}$ & $\begin{array}{l}\text { - Missing: } \\
\text { 24,25,36 and } 46\end{array}$ \\
\hline Microbiological profile & $\begin{array}{l}\text { - Presence of Aggregatibacteracti- } \\
\text { nomycemtemcomitans }(\mathrm{Aa})\end{array}$ & - & $\begin{array}{l}\text { - Presence of Aggregatibacteracti- } \\
\text { nomycetemcomitans }(\mathrm{Aa})\end{array}$ \\
\hline Biochemical analysis & $\begin{array}{l}\text { - Serum calcium: } 10.3 \mathrm{mg} \% \\
\text { (Normal 9-11 mg\%) } \\
\text { Alkaline phosphatase: } 134.04 \\
\text { units/l } \\
\text { (Normal: } 25-140 \text { units/l) } \\
\text { - No abnormality detected }\end{array}$ & & - No abnormality detected \\
\hline $\begin{array}{l}\text { Immunological } \\
\text { analysis }\end{array}$ & $\begin{array}{l}\text { - levels of IgG within normalcy } \\
2.42 \mathrm{~g} / \mathrm{l}(\text { Normal } 0.7-4.10 \mathrm{~g} / \mathrm{l})\end{array}$ & & - Levels of IgG within normalcy \\
\hline Biopsy report & $\begin{array}{l}\text { Suggestive of fibroepithelial } \\
\text { hyperplasia superimposed } \\
\text { chronic inflammatory changes }\end{array}$ & & $\begin{array}{l}\text { Fibroepthelial hyperplasia super- } \\
\text { imposed chronic inflammatory } \\
\text { changes }\end{array}$ \\
\hline Diagnosis & $\begin{array}{l}\text { Generalized aggressive peri- } \\
\text { odontitis with Idiopathic gingival } \\
\text { enlargement. }\end{array}$ & & $\begin{array}{l}\text { - Generalized aggressive perio- } \\
\text { dontitis with Idiopathic gingival } \\
\text { enlargement. }\end{array}$ \\
\hline Treatment: & $\begin{array}{l}\text { Phase I therapy } \\
\text { - Extraction of hopeless teeth: } \\
24,25,26 \text { and } 36 \\
\text { - Thorough scaling root planning } \\
\text { Phase II therapy } \\
\text { - Internal bevel gingevectomy } \\
\text { which permitted adequate con- } \\
\text { touring of tissues } \\
\text { - Periodic revaluation } \\
\text { - The condition resolved after pro- } \\
\text { fessional care and maintenance } \\
\text { by the patient (Fig. } 2 \text { ) }\end{array}$ & & $\begin{array}{l}\text { Phase I therapy: } \\
\text { - Extraction of hopeless teeth: } \\
12,14,16,22,23,24,27,35 \text { and } \\
46 \\
\text { - Thorough scaling root planing } \\
\text { Phase II therapy } \\
\text { Excision of gingival enlargement } \\
\text { with cauterization and } \\
\text { Phase III therapy: } \\
\text { Followed by prosthetic reha- } \\
\text { bilitation using treatment partial } \\
\text { denture (Fig. 5) }\end{array}$ \\
\hline Follow up & $\begin{array}{l}\text { Phase IV therapy: } \\
\text { - She was scheduled for every six } \\
\text { months rigorous follow-up which } \\
\text { involved reinforcement of oral } \\
\text { hygiene instructions and scaling } \\
\text { root planning for two years till } \\
2006\end{array}$ & $\begin{array}{l}\text { Phase IV therapy: } \\
\text { - Scheduled for follow-up } 6 \text { monthly. } \\
\text { The patient failed to report for timely } \\
\text { follow-ups later }\end{array}$ & $\begin{array}{l}\text { Phase IV therapy: } \\
\text { - Local delivery of Gengigel } 0.2 \% \\
\text { hyaluronic acid for } 2 \text { weeks adjunct } \\
\text { to scaling root planning } \\
\text { - Ongoing }\end{array}$ \\
\hline
\end{tabular}




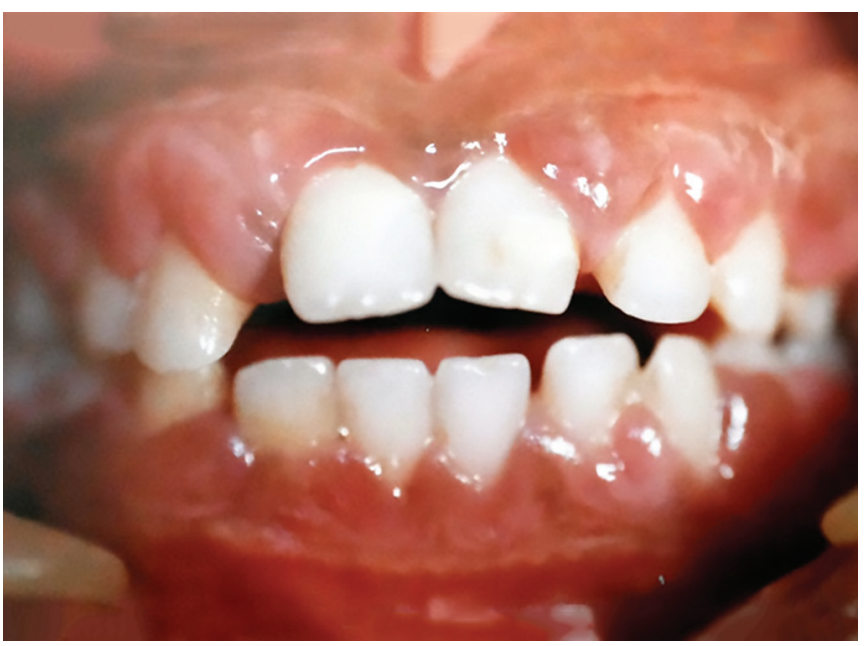

Fig. 1: Preoperative frontal view

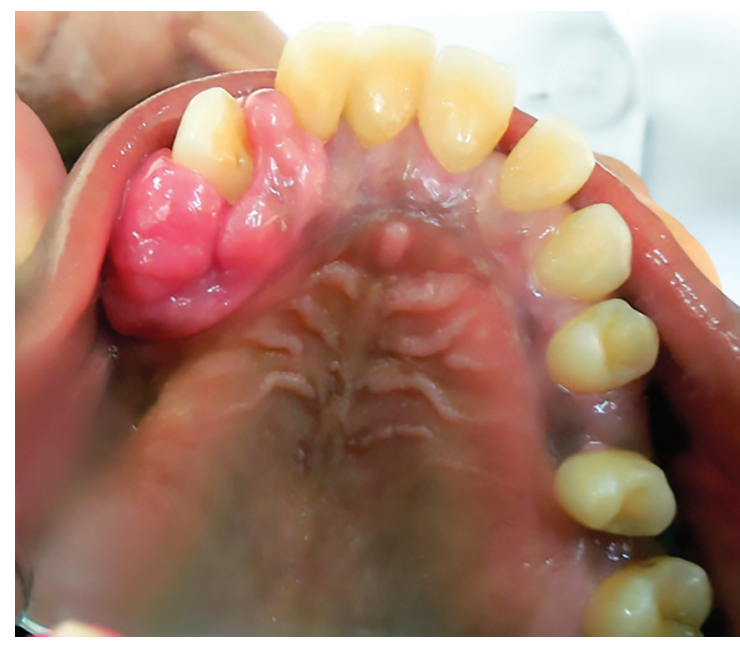

Fig. 3: Palatal view

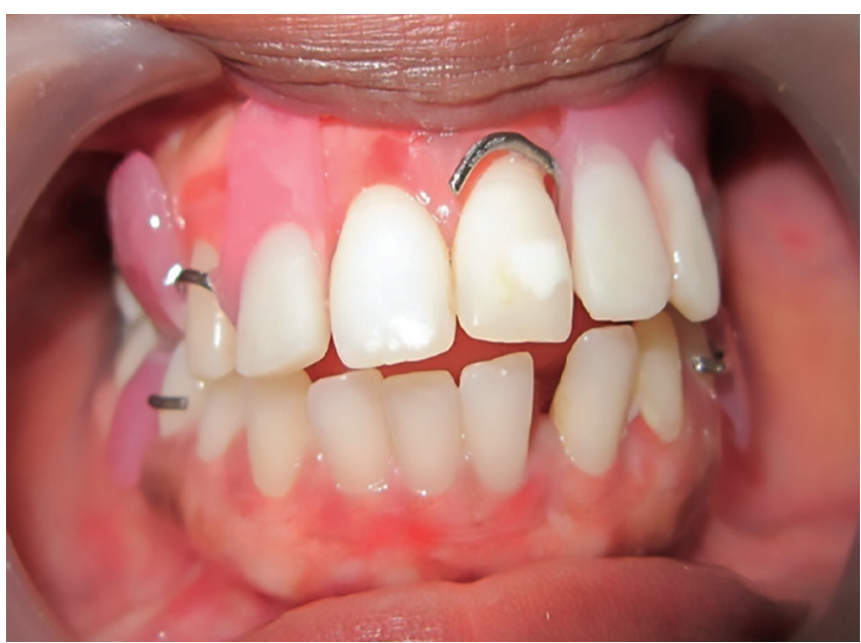

Fig. 5: Frontal view after prosthetic rehabilitation

Aggressive periodontitis (AP) is a rare form of periodontitis that may be localized (LAP) or generalized (GAP) depending on the clinical and laboratory findings. In the current case, the clinical findings along with radiographical and microbiological data strongly suggested the diagnosis of GAP. Gingival enlargements are rarely found in cases of GAP. Similar cases have been reported

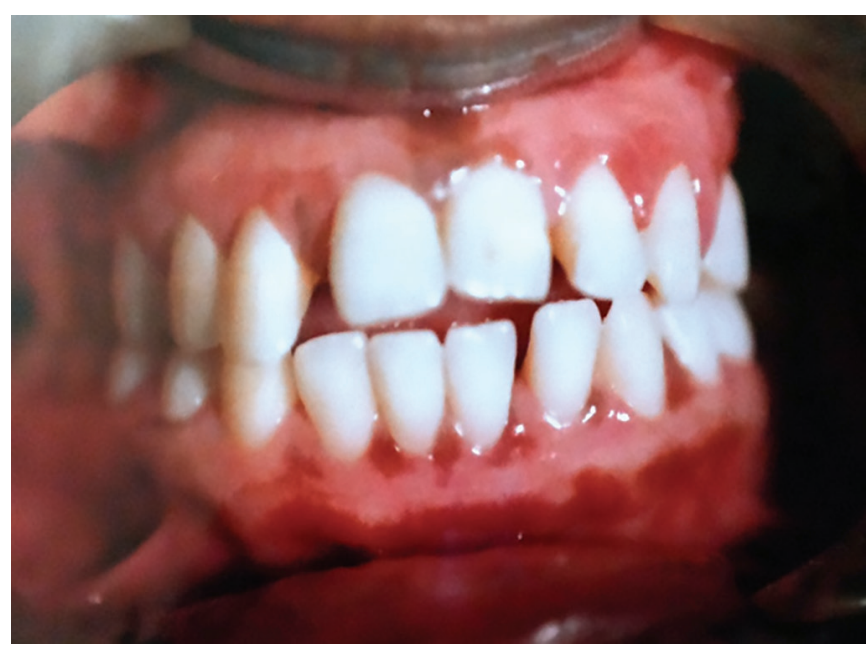

Fig. 2: Postoperative frontal view

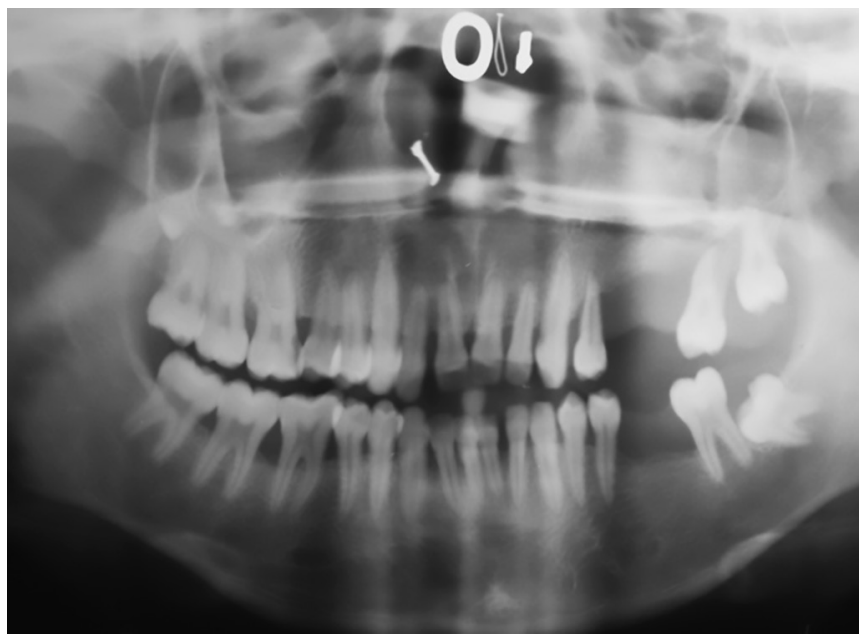

Fig. 4: OPG, 2006

by are Mahajan et al., ${ }^{6}$ Chaturvedi, ${ }^{7}$ Vishnoi et al., ${ }^{8}$ and Shetty et al. ${ }^{9}$ cases reported so far are in female patients in the age group of 14 to 23 years of age. They presented with similar chief complaint of more or less similar oral periodontal findings.

The treatment plan included gingivectomy using conventional and electrosurgery. The advantages of electro-surgery being tissue separation are clean, with little or no bleeding, so that clear view of the surgical site was provided. It provides planning of soft tissue and better access to difficult-to-reach areas. The healing discomfort and scar formation are minimal, along with reduced chair time and operator fatigue. The technique will be pressureless and precise.

The treatment also involved the application of $0.2 \%$ hyaluronic acid (Gengigel ${ }^{\circledR}$ ) intrasulularly for 3 weeks. Gengigel is an effective agent for treatment of plaqueinduced gingivitis along with scaling as well as an intramuscular application providing a better result compared to the only topical application. Gengigel along with SRP have shown improvement in gingival parameters. ${ }^{5}$ Extraction of teeth with poor periodontal prognosis was 
unavoidable. A removable partial denture was provided instead of fixed partial denture owing to poor bone support from the abutment teeth. Successfully treated cases of GAP may show relapse ${ }^{10}$ keeping this in mind instructions were given to the patient to follow up every 3 months for oral hygiene reinforcement and scaling and root planning.

\section{CONCLUSION}

In GAP, rapid destruction of periodontal tissues can be prevented by early diagnosis. Also, diagnosis of GAP can be complicated by associated conditions like gingival enlargement. Therefore, the diagnosis should be given, based on complete history radiographical microbiological and clinical findings. The use of local application of agents such as Gengigel ${ }^{\circledR}$ is recommended to improve the periodontal conditions.

\section{REFERENCES}

1. Carranza FA, Hogan EL. Gingival enlargement. In: Newman MG, Takei HH, Carranza FA. Clinical periodontology. 9th ed. Philadelphia: Saunders; 2006.p.373-339
2. Armitage GC. Development of a classification system for periodontal diseases and conditions. Ann Periodontol. 1999;4:1-6

3. Tonetti M, Mombelli A. Early onset periodontitis. Ann Periodontol 1999;4:39-52.

4. Novak KF. Aggressive periodontitis. In: Newman MG, Takei $\mathrm{HH}$, Carranza FA. Clinical periodontology. 10th ed. Philadelphia: Saunders; 2006.p.506-512.

5. Sapna N, Vandana KL. Evaluation of hyaluronan gel (Gengigel ${ }^{\circledR}$ ) as a topical applicant in the treatment of gingivitis. Journal of investigative and clinical dentistry. 2011 Aug;2(3):162-170.

6. Mahajan A, Dixit J, Umesh V. An intriguing case of gingival enlargement associated with generalized aggressive periodontitis. PERIO 2007;4:295-299.

7. Chaturvedi R. Idiopathic gingival fibromatosis associated with generalized aggressive periodontitis: A case report. J Can Dent Assoc 2009;75:291-295.

8. Vishnoi SL, Phadnaik MB. Unsual Gingival enlargement with aggressive periodontitis:A case report. J Contemp Dent Pract. 2010;11:49-55.

9. Shetty A, Gupta N, Shetty D, Kadakia R. Idiopathic gingival enlargement associated with generalized aggressive periodontitis in a 19-year-old female. Journal of Indian Society of Periodontology. 2014 Mar;18(2):244-248.

10. Waerhaug J. Plaque control in the treatment of juvenile periodontitis. Journal of Clinical Periodontology. 1977 Mar;4(1):29-40. 